\title{
PENGARUH PENDEKATAN PENDIDIKAN MATEMATIKA REALISTIK BERBASIS OPEN ENDED TERHADAP KEMAMPUAN BERPIKIR SISWA SD KELAS V
}

\author{
I Kadek Agus Alit Dwipayana \\ Jurusan Pendidikan Guru Sekolah Dasar, Universitas Pendidikan Ganesha \\ E-mail: agus.alit.dwipayana@gmail.com
}

Desak Putu Parmiti

Jurusan Pendidikan Guru Sekolah Dasar, Universitas Pendidikan Ganesha

E-mail: dskpt_parmiti@yahoo.com

Komang Sujendra Diputra

Jurusan Pendidikan Guru Sekolah Dasar, Universitas Pendidikan Ganesha

E-mail: sujendra.pgsd@gmail.com

\begin{abstract}
Abstrak
Penelitian ini bertujuan untuk mengetahui perbedaan kemampuan berpikir kreatif Matematika antara kelompok siswa yang mengikuti pembelajaran menggunakan pendekatan PMRI berbasis open-ended dan kelompok siswa yang mengikuti pembelajaran tidak menggunakan pendekatan PMRI berbasis open-ended pada siswa kelas V SD di Gugus VII Kecamatan Sukasada Tahun Pelajaran 2017/2018. Penelitian ini merupakan penelitian eksperimen semu dengan desain post test only controlgroup design. Populasi penelitian ini adalah seluruh kelas V SD di Gugus VII Kecamatan Sukasada yang berjumlah 6 kelas dengan jumlah siswa sebanyak 120 orang. Penentuan sampel dilakukan dengan teknik randomsampling. Pengumpulan data dalam penelitian ini dilakukan menggunakan metode tes. Instrumen pengumpulan data yang digunakan berupa tes uraian. Data yang telah dikumpulkan, dianalisis menggunakan analisis statistik deskriptif dan inferensial (t burning dan anava satu jalur). Hasil pengujian hipotesis menunjukkan bahwa nilai efektivitas size (ES) sebesar 1,028 yang berada kedalam efektivitas tinggi $(0,8<1,7)$, selanjutnya f-hitung yaitu sebesar 230,598 lebih dari nilai t-tabel yang sebesar 4.03 , yang diuji pada taraf signifikansi $5 \%$ dengan $\mathrm{db}_{\text {antar }}=1$ dandb $b_{\text {dalam }}=50$. Hal ini berarti bahwa pembelajaran menggunakan pendekatan PMRI berbasis open-ended menunjukkan efektivitas tinggi dan terdapat perbedaan kemampuan berpikir kreatif Matematika antara kelompok siswa yang mengikuti pembelajaran menggunakan pendekatan PMRI berbasis open-ended dan kelompok siswa yang mengikuti pembelajaran tidak menggunakan pendekatan PMRI berbasis open-ended. Dengan demikian, pendekatan PMRI berbasis openended berpengaruh terhadap kemampuan berpikir kreatif Matematika siswa kelas V SD di Gugus VII Kecamatan Sukasada tahun pelajaran 2017/2018.
\end{abstract}

Kata kunci: PMR, kemampuan berpikir kreatif, Matematika.

\begin{abstract}
This study aims to determine the differences of creative thinking ability of Mathematics between groups of students who follow the learning using an open-ended PMRI approach and groups of students who follow the lesson did not use PMRI approach based on open-ended V-grade students in Gugus VII Sukasada sub-districts Lesson 2017 / 2018. This research is a quasi experiment research with post test design only control group design. The population of this research is all of class V SD in Sukasada District VII Cluster of 6 classes with the number of students as many as 120 people. Sample determination was done by random sampling technique. Data collection in this study was conducted using the test method. The data collection instrument used is a description test. The data have been collected, analyzed using descriptive and inferential statistical analysis (t burning and one path anava). The result of hypothesis testing shows that the value of effectiveness of size (ES) is 1.028 which is in high effectiveness $(0,8<1,7)$, then $\mathrm{f}$-count is 230,598 more than t-table value equal to 4.03 , which tested at significance level $5 \%$ dbantar $=1$ and dbd $=50$. This means that learning using an open-ended PMRI approach shows high effectiveness and there is a difference in creative thinking ability. Mathematics between groups of students following learning using an open-ended PMRI approach and groups of students following the lesson did not use an open-ended PMRI approach. Thus, the open-ended PMRI approach has an effect on the creative thinking ability of V grade V elementary students in Sukasada District VII Cluster of the 2017/2018 school year.
\end{abstract}

Keywords: PMR, creative thinking ability, Math.

Pengaruh Pendekatan Pendidikan Matematika Realistik Berbasis Open Ended

Terhadap Kemampuan Berpikir Siswa Sd Kelas V 


\section{PENDAHULUAN}

Matematika merupakan suatu ilmu yang memiliki peran penting dalam kehidupan sehari-hari. Aktivitas manusia dalam kehidupan sehari-hari tidak lepas dari pemanfaatan dan penerapan konsep-konsep yang ada dalam matematika Sarismah (dalam Lestari, 2014). Selain itu, "Matematika merupakan salah satu bidang studi yang ada pada semua jenjang pendidikan, mulai dari tingkat sekolah dasar hingga perguruan tinggi. Bahkan matematika diajarkan di taman kanak-kanak secara informal" (Susanto, 2013:183). Pembelajaran matematika di sekolah memberikan sumbangan yang penting bagi siswa dalam pengembangan kemampuan. Dalam Kurikulum Tingkat Satuan Pendidikan (KTSP) mata pelajaran matematika (BNSP, 2006), pembelajaran matematika di sekolah bertujuan agar peserta didik:

1. Memahami konsep matematika, menjelaskan keterkaitan antar konsep dan mengaplikasikan konsep atau algoritma, secara luwes, akurat, efisien, dan tepat dalam pemecahan masalah.

2. Menggunakan penalaran pada pola dan sifat, melakukan manipulasi matematika dalam membuat generalisasi, menyusun bukti, atau menjelaskan gagasan dan pernyataan matematika.

3. Memecahkan masalah yang meliputi kemampuan memahami masalah, merancang model matematika, menyelesaikan model dan menafsirkan solusi yang diperoleh.menggunakan matematika sebagai cara bernalar yang dialihgunakan pada keadaan seperti berfikir logis, kritis, sistematis, disiplin dalam memandang dan menyelesaikan masalah.

4. Mengomunikasikan gagasan dengan simbol, tabel, diagram, atau media lain untuk memperjelas keadaan atau masalah.

5. Memiliki sikap menghargai kegunaan matematika dalam kehidupan, yaitu memiliki rasa ingin tahu, perhatian, dan minat dalam mempelajari matematika serta sikap ulet dan percaya diri dalam pemecahan masalah.

Menurut Putra dkk (2012), salah satu tujuan pembelajaran matematika adalah agar siswa memiliki kemampuan berpikir kreatif. Kemampuan berpikir kreatif merupakan salah satu faktor penting dari tujuan pembelajaran karena memberi pengetahuan semata-mata kepada siswa tidak akan banyak menolongnya dalam kehidupan sehari-hari, sehingga dalam pembelajaran sebaiknya dapat mengembangkan sikap dan kemampuan peserta siswa yang dapat membantu untuk menghadapi persoalan-persoalan di masa mendatang secara kreatif.

Sedangkan menurut Siswono dan Novitasari (2007) mengatakan bahwa untuk meningkatkan kemampuan berpikir kreatif siswa dalam pembelajaran matematika, perlu dilaksanakan pembelajaran yang memberi kesempatan kepada siswa untuk mengembangkan kemampuan berpikir kreatifnya. Salah satu pembelajaran yang memberi kesempatan kepada siswa untuk dapat mengembangkan kemampuan berpikir kreatifnya adalah pembelajaran berbasis masalah. Pembelajaran berbasis masalah membiasakan siswa untuk berpikir secara divergen. Sebagaimana yang dinyatakan bahwa dengan adanya masalah menuntut siswa untuk mengembangkan pola pikirnya dalam memecahkan masalah tersebut. Disamping itu, salah satu tujuan siswa dilatih menyelesaikan masalah salah satunya adalah untuk meningkatkan motivasi dan menumbuhkan sifat kreatif.

Namun kemampuan memecahkan masalah siswa di Indonesia masih sangat lemah. Hal tersebut tercermin dari hasil tes TIMSS (Trend in International Mathematics and Science Study), survei interasional tentang prestasi matematika memperlihatkan bahwa skor yang diraih Indonesia masih dibawah rata-rata skor internasional. Hasil study TIMSS tahun 2015, Indonesia berada diperingkat ke-45 dari 50 negara peserta dengan skor rata-rata 397, sedangkan skor rata-rata internasional adalah 500.Jika dibandingkan dengan Negara ASEAN, misal singapura, posisi Indonesia masih jauh dibawah Negara tersebut. Hasil study TMSS 2015, singapura berada pada peringkat ke1 dengan skor rata-rata 605 (OECD, 2016).

Kenyataan di atas terjadi pula di Gugus VII Kecamatan Sukasada, berdasarkan hasil wawancara yang dilakukan pada tanggal 15-18 Desember 2017 dengan guru kelas V dan siswa kelas V SD di Gugus VII Kecamatan Sukasada menunjukkan bahwa guru sebenarnya sudah melakukan/menerapkan model-model yang inovatif, namun dalam prosesnya masih terdapat beberapa kendala yang dihadapi guru maupun siswa. Beberapa kendala tersebut adalah masih kurangnya pemahaman guru terhadap model yang diterapkan, selain itu pemilihan model yang diterapkan kurang sesuai dengan lingkungan siswa dan belum berbasis pemecahan masalah. Hal tersebut mempengaruhi proses pembelajaran dan mengakibatkan pembelajaran belum sepenuhnya menjadikan siswa sebagai objek dari pembelajaran tersebut.

Hasil observasi di kelas menunjukkan dalam penerapan model yang dipilih kurang didukung oleh mediamedia yang mendukung. Hal ini sangat disayangkan, padahal dilingkungan sekitar sekolah tersebut banyak terdapat benda-benda yang bisa dijadikan media dalam menyampaikan materi. Dalam penyampaian pembelajaran guru juga masih terfokus dengan apa yang ada pada buku ajar, lebih dominan permasalahan-permasaahan disampaikan 
sebagaimana yang ada di buku paket dan tidak dikaitkan dengan permasalahan nyata siswa di kelas tersebut. Alasan yang paling mendasar guru tidak maksimal dalam menerapkan model pembelajaran adalah pencapaian materi. Guru yang telah menggunakan model pembelajaran yang inovatif diharuskan kembali menggunakan model pembelajar yang dominan ceramah dan berpusat pada guru, hal tersebut dikarenakan guru harus mengejar pencapaian materi yang sangat padat. Sistem pembelajaran yang demikian menyebabkan siswa tidak berpartisipasi aktif dalam mengikuti pembelajaran dan tidak dapat meningkatkan aktivitas belajar matematika untuk meningkatakan pengembangan kemampuanya.

Diidentifikasi rendahnya nilai siswa dikarenakan dalam kesehariannya siswa lebih sering diajarakan soalsoal yang penyelesaiaannya bersifat procedural. Ketika dihadapkan dengan soal berbentuk soal cerita/penyelesaian masalah siswa masih mengalami kesulitan dalam menyelesaikannya. Hal tersebut menjadi tolak ukur bahwa siswa di sekolah tersebut belum mampu mengembangkan kemampuan berpikir kreatif dalam memahami dan menjawab soal. Hasil studi TIMSS juga menunjukkan hasil yang serupa, siswa Indonesia lebih menguasai penyelesaian soal rutin dan kurang dalam penyeleaian soal yang menuntut siswa untuk bernalar (OECD, 2016).

Melihat kondisi yang seperti ini, perlu kiranya melakukan peningkatan kualitas dalam pembelajaran matematika, yakni pembelajaran yang mengoptimalkan interaksi setiap elemen untuk menumbuhkembangkan kemampuan berpikir siswa. Upaya mengembangkan kemampuan berpikir kratif siswa dapat dilakukan dengan jalan menggunakan model/pendekatan yang inovatif dan memberi kesempatan siswa untuk lebih aktif beraktivitas dan berpartisipasi dalam proses pembelajaran. Salah satu pendekatan yang memberikan kesempatan kepada siswa untuk aktif dalam kegiatan pembelajaran adalah pendekatan pendidikan matematika realistik (PMR).

Pendekatan pendidikan matematika realistis (PMR) sangat populer dan dikenal di beberapa Negara dengan sebutanRealistic Mathematics Education. PMR merupakan salah satu pendekatan pembelajaran matematika yang berorientasi pada siswa. Matematika adalah aktivitas manusia dan matematika harus diubungkan secara nyata terhadap konteks kehidupan sehari-hari siswa ke pengalaman belajar yang berorientasi pada hal-hal yang real (nyata) Susanto (2013).

Sebagaimana yang dikemukakan oleh Marhamah (dalam Lestari, 2014) bahwa pendekatan matematika realistik cocok digunakan dalam pembelajaran matematika karena PMR memiliki karakteristik dan prinsip yang memingkinkan siswa dapat berkembang secara optimum, seperti kebebasan siswa untuk menyampaikan pendapatnya, adanya masalah kontekstual yang dapat mengaitkan konsep matematika dengan kehidupan nyata, dan pembuatan model yang dapat memudahkan siswa dalam menyelesaikan masalah.

Suatu prinsip utama PMR adalah siswa harus berpartisipasi secara aktif dalam proses belajar. Siswa harus diberikan kesempatan untuk membangun pengetahuan dan pemahaman mereka sendiri. Konsep-konsep matematika yang abstrak perlu ditransformasikan menjadi hal-hal yang berifat real bagi siswa. Dengan menjadikan masalah matematika bersifat nyata siswa akan lebih kreatif dalam mengembangkan alternatif-alternatif jawaban, sehingga dapat meningkatkan kemampuan berpikir kreatif siswa.

Kemampuan berpikir kreatif siswa akan lebih bermakna apabila masalah matematika yang dibuat menjadi nyata selanjutnya disajikan dengan permasalahan open-ended. Menurut Suherman (2004) Permasalahan open-ended adalah sebuah permasalahan yang mempunyai banyak jawaban benar. Jadi dengan menyajikan masalah matematika melalui permasalahan open-ended memicu siswa untuk mengembangkan kemampuan kreatif siswa dalam memecahkan masalah .hal ini dikarenakan permasalahan open-ended memberikan kesempatan kepada siswa untuk mencari banyak jawaban yang benar dengan berbagai alternatif penyelesaian.

Berdasarkan pemaparan di atas, diduga terdapat perbedaan kemampuan berpikir kreatif siswa yang menggunakan pendekatan pendidikan matematika realaistik Berbasis Open Ended dengan siswa yang tidak menggunakan pendekatan pendidikan matematika realistik Berbasis Open Ended. Oleh karena itu, diperlukan melakukan kajian tentang pendekatan yang paling efektif dalam upaya untuk meningkatkan kemampuan berpikir kratif siswa, sehingga difokuskan penelitian yang berjudul Pengaruh Pendekatan Pendidikan Matematika Realistik Berbasis Open Ended Terhadap Kemampuan Berpikir Kreatif Matematika Siswa Kelas V Di Gugus VII Sukasada Tahun Pelajaran 2017/2018

\section{Metode Penelitian}

Tempat pelaksanaan penelitian ini adalah di Gugus VII Kecamatan Sukasada Kabupaten Buleleng.Kegiatan penelitian ini dilaksanakan pada semester II, tahun pelajaran 2017/2018. Jenis penelitian yang dilakukan adalah penelitian eksperimen. Jenis penelitian yang digunakan adalah penelitian kuantitatif yaitu penelitian eksperimen dengan desain eksperimen semu (quasy experimental design). Sugiyono (2014:114) memaparkan bahwa, "Desain eksperimen semu (quasy experimental design) mempunyai kelompok kontrol tetapi tidak dapat berfungsi sepenuhnya untuk mengontrol variabel-variabel luar yang memengaruhi pelaksanaan eksperimen." Hal ini dikarenakan kemampuan peneliti dalam mengamati perilaku siswa terbatas terutama ketika siswa berada di luar sekolah. Bentuk desain eksperimen semu (quasy experimental design) yang digunakan dalam penelitian ini yaitu 
post-test only control group design. Rancangan penelitian yang digunakan dalam penelitian ini adalah post-test only control group design. Rancangan penelitiannya dapat digambarkan sebagai berikut.

Tabel 1.

Non Equivalent Post-test Only Control Group Design

(Dimodifikasi dari Sugiyono 2015)

\begin{tabular}{ccc}
\hline Kelas & Treatmen & Post-test \\
\hline $\mathrm{KE}$ & $\mathrm{X}$ & $\mathrm{O}_{1}$ \\
\hline $\mathrm{KK}$ & - & $\mathrm{O}_{2}$ \\
\hline
\end{tabular}

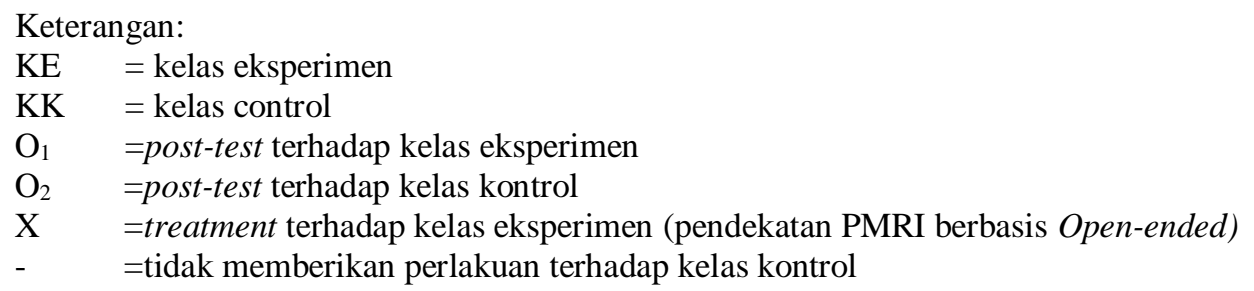

Populasi dalam penelitian ini adalah seluruh siswa V di Gugus VII Kecamatan Sukasada, Kabupaten Buleleng Tahun Pelajaran 2017/2018. Gugus ini terdiri dari enam sekolah, sehingga terdapat enam kelas dengan jumlah seluruh siswanya sebanyak 120 orang.Teknik yang digunakan untuk mengambil sampel yaitu teknik group random Sampling.

Dari kedelapan SD di Gugus VII Kecamatan Sukasada yang sudah di uji kesetaraanya, diadakan undian untuk mengambil 2 kelas yang menjadi sampel penelitian. Hasil undian diperoleh dua kelas yaitu kelas V SD Negeri 4 Selat dan SD Negeri 2 Selat. Kedua kelas tersebut di undi kembali untuk menentukan kelas eksperimen dan kontrol. Hasil dari pengundian tersebut yaitu SD Negeri 2 Selat sebagai kelas eksperimen dan SD Negeri 4 Selat sebagai kelompok kontrol. Satu kelas yang mendapat perlakuan pendekatan PMRI berbasis open-ended dan satu kelas tidak dibelajarkan dengan pendekatan PMRI berbasis open-ended.

Data yang diperlukan dalam penelitian ini adalah data kemampuan berpikir kreatif matematika siswa. Untuk mengumpulkan data hasil belajar tersebut, dalam penelitian ini digunakan metode tes. Metode tes ini dilakukan dengan membagikan sejumlah tes untuk mengukur hasil belajar matematika. Pemberian post test merupakan teknik pengumpulan data tentang kemampuan berpikir kreatif matematika siswa kelas V SD Gugus VII Kecamatan Sukasada, Kabupaten Buleleng. Terbatas hanya kemampuan kognitif siswa. Tes yang diberikan pada penelitian ini adalah tes uraian.

Dalam penelitian ini, data dikumpulkan dengan memberikan tes pada setiap individu. Pengumpulan datakemampuan berpikir kreatif matematika dilakukan pada siswa kelas V SD di Gugus VII Kecamatan Sukasada Kabupaten Buleleng Tahun Pelajaran 2017/2018.

Dalam penelitian ini teknik pengumpulan data yang digunakan adalah metode tes. Metode tes yang digunakan dalam penelitian ini adalah cara memperoleh data berbentuk suatu tugas yang dilakukan atau dikerjakan oleh seseorang atau kelompok yang dites (testee) dan menghasilkan suatu data berupa skor (interval). Tes dilakukan pada akhir pembelajaran yang bertujuan untuk mengukur kemampuan siswa. Tes tersebut kemudian diuji coba lapangan untuk mencari validitas, reabilitas, taraf kesukaran dan daya bedanya. Hasil tes uji lapangan akan diberikan kepada siswa kelas eksperimen dan kontrol. Teknik analisis data yang digunakan adalah T- burning untuk mencari efektivitas pendekatan PMRI berbasis open-ended terhadap kemampuan berpikir kreatif siswa kelas V di Gugus VII Kecamatan Sukasada Kabupaten Buleleng Tahun Pelajaran 2017/2018 dan Anava Satu Jalur untuk mencari pengaruh pendekatan PMRI berbasis open-ended terhadap kemampuan berpikir kreatif siswa kelas V di Gugus VII Kecamatan Sukasada Kabupaten Buleleng Tahun Pelajaran 2017/2018.

\section{HASIL DAN PEMBAHASAN \\ Hasil Penelitian}

Untuk mengetahui efektivitas dan pengaruh yang signifikan pendekatan PMRI berbasis open-ended terhadap kemampuan berpikir kreatif siswa kelas V di Gugus VII Kecamatan Sukasada Kabupaten Buleleng Tahun Pelajaran 2017/2018 menggunakan t-burning dan Anava Satu Jalur. Rekapitulasi perhitungan skor hasil belajar Matematika siswa tersedia pada Tabel 2. 
Tabel 2. Rekapitulasi Perhitungan Sko Kemampuan Berpikir Kreatif Matematika Siswa

\begin{tabular}{|c|c|c|}
\hline \multirow{2}{*}{ Statistik } & \multicolumn{2}{|c|}{ Hasil Belajar Matematika } \\
\hline & Kelompok Eksperimen & Kelompok Kontrol \\
\hline Mean & 98.259 & 57,24 \\
\hline Median & 98,923 & 56 \\
\hline Modus & 99,45 & 52,33 \\
\hline Varians & 85.507 & 104.69 \\
\hline Standar Deviasi & 9,247 & 10.232 \\
\hline
\end{tabular}

Bedasarkan tabel di atas dapat dideskripsikan mean (M), median (Md), modus (Mo), varians, dan standar deviasi (s) dari data kemampuan berpikir kreatif kelompok eksperimen, yaitu: Mean $(M)=98,259$, median $($ Md $)=$ 98,923, modus $(M o)=99,45$, varians $(s 2)=85,507$ dan standar deviasi $(s)=9,247$. Pada kelompok eksperimen diketahui bahwa modus lebih besar dari median dan median lebih besar dari mean $(99,45>98,923>98,259)$. Sehingga kurva yang terbentuk adalah adalah kurva juling negatif yang artinya skor cenderung tinggi. Kurva juling negatif kemampuan berpikir kreatif kelas eksperimen dapat dilihat pada Gambar 1.

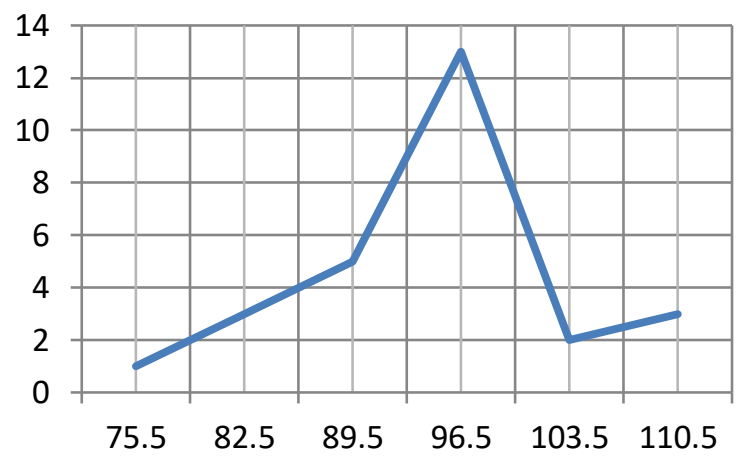

Gambar 1.

Kurva Juling Negatif Data Post-test Matematika Kelompok Ekperimen

Pada kelompok kontrol dapat dideskripsikan mean (M), median (Md), modus (Mo), varians $\left(\mathrm{s}^{2}\right)$, dan standar deviasi (s) dari data hasil belajar kognitif Matematika kelompok kontrol, yaitu Mean $(\mathrm{M})=57,24$, median $(\mathrm{Md})=56$, modus $(\mathrm{Mo})=52,33$, varians $\left(\mathrm{s}^{2}\right)=104.69$ dan standar deviasi $(\mathrm{s})=10.232$. Jika mean lebih besar dari median dan lebih besar dari modus $(57,24>56>52,33)$. Sehingga kurva yang terbentuk menggambarkan kurva juling positif yaitu sebagian besar skor kelompok kontrol cenderung rendah. Kurva juling positif kemampuan berpikir kretif kelompok kontrol dapat disajikan pada Gambar 2.

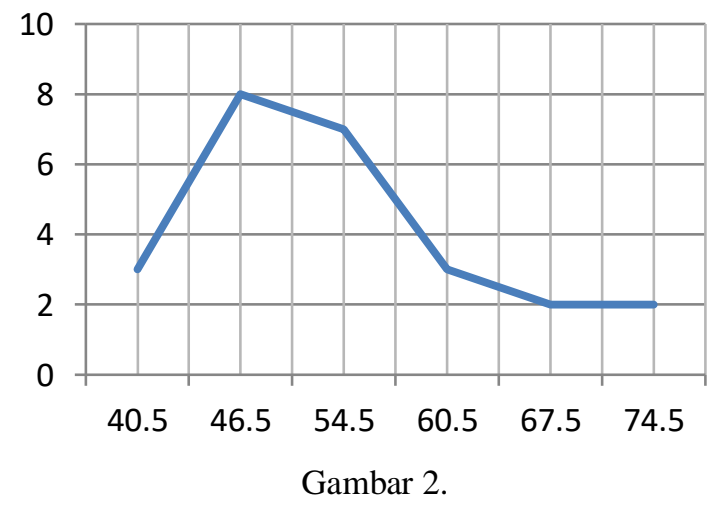

Kurva Juling Negatif Data Post-test Matematika Kelompok Ekperimen 
Dari pemaparan di atas, skor rata-rata hasil belajar matematika kelompok eksperimen lebih tinggi dibandingkan kelompok kontrol. Sebelum melakukan uji hipotesis maka harus dilakukan beberapa uji prasyarat, uji prasyarat analisis meliputi uji normalitas dan uji homogentias varians.

Uji normalitas sebaran data dilakuan terhadap data hasil belajar kelompok eksperimen dan kontrol. Normalitas sebaran data diuji dengan menggunakan rumus Chi-Kuadrat $\left(\chi^{2}\right)$, dengan kriteria pengujian data berdistribusi normal jika $\chi_{\text {hitung }}^{2}<\chi_{\text {tabel }}^{2}$ pada taraf signifikansi $5 \%$ dan derajat kekebasan dk=(jumlah kelas parameter - 1). Berdasarkan hasil perhitungan dengan menggunakan rumus chi-kuadrat, kemampuan berpikir kreatif kelompok eksperimen adalah (harga $X^{2}$ Hitung $=6,554<X^{2}$ tabel $=9,49$ ), sehingga data kemampuan berpikir kreatif kelompok eksperimen berdistribusi normal. Sedangkan hasil belajar kelompok kontrol adalah (harga $\mathrm{X}^{2}$ Hitung $=4,147<\mathrm{X}^{2}$ tabel $=5,99$ ), sehingga data hasil belajar kelompok kontrol berdistribusi normal.

Setelah melakukan uji normalitas, maka dilanjutkan dengan uji homogenitas. Uji homogenitas dilakukan untuk mengetahui apakah data dari kedua kelompok homogen atau tidak. Uji homogenitas dihitung dengan cara membagi varians terbesar dengan varians terkecil. Data dinyatakan homogen apabila $\mathrm{F}_{\text {hitung }}<\mathrm{F}_{\text {tabel }}$ dengan taraf signifikansi $5 \%$. Berdasarkan hasil uji $\mathrm{F}$ diperoleh $\mathrm{F}_{\text {hitung }}$ sebesar 1,22 sedangkan $\mathrm{F}_{\text {tabel }}$ dengan $\mathrm{db}_{\text {pembilang }}=25-1=24$, $\mathrm{db}_{\text {penyebut }}=27-1=26$, pada taraf signifikansi $5 \%$ adalah 1,97 . Hal ini berarti $\mathrm{F}_{\text {hitung }}$ lebih kecil dari $\mathrm{F}_{\text {tabel }}$. Sehingga dapat dinyatakan bahwa varians data hasil post-test kelompok eksperimen dan kontrol adalah homogen.

Setelah melakukan analisis deskripsi dan uji prasyarat, maka dilanjutkan dengan melakukan uji hipotesis yaitu terdapat pengaruh secara efektif implementasi pendekatan pendidikan matematika realistic berbasis openended terhadap kemampuan berpikir kreatif siswa kelas V di Gugus VII Kecamatan Sukasada Tagun Pelaajaran 2017/2018. Pengujian hipotesis tersebut dilakukan melalui T-burning.

Analisis dengan T-burning menunjukkan bahwa harga efektivitas size (ES) adalah 1,028. Jika dimasukkan dalam kriteria untuk menentukan efektivitas, maka nilai tersebut berada pada $(0.8<1,7)$ yang artinya memiliki efektivitas tinggi.

Selanjutnya, untuk uji hipotesis yaitu terdapat pengaruh yang signifikan antara kelompok yang dibelajarkan menggunakan pendekatan pendidikan matematika realistic berbasis open-ended terhadap kemampuan berpikir kreatif siswa kelas V di Gugus VII Kecamatan Sukasada Tagun Pelaajaran 2017/2018. Pengujian hipotesis tersebut dilakukan melalui Anava satu jalur. Tabel 4

Rangkuman hasil perhitungan Anava satu jalur antar kelompok eksperimen dan kontrol Dapat dilihat pada

Tabel 4. Rangkuman Hasil Perhitungan

\begin{tabular}{|c|c|c|c|c|c|c|c|}
\hline \multirow[t]{2}{*}{ Sumber Varian } & \multirow{2}{*}{ JK } & \multirow[t]{2}{*}{ Db } & \multirow[t]{2}{*}{ RJK } & \multirow[t]{2}{*}{ Fh } & \multicolumn{2}{|c|}{ Ftab } & \multirow[t]{2}{*}{ Keputusan } \\
\hline & & & & & $5 \%$ & $1 \%$ & \\
\hline $\operatorname{antar} \mathrm{A}$ & $21.841,18$ & 1 & $21.841,18$ & 230,59 & 4.03 & 7.17 & signifikan \\
\hline Dalam & $4.735,745$ & 50 & 94,715 & & & & \\
\hline Total & $26.576,92$ & 51 & & & & & \\
\hline
\end{tabular}

Berdasarkanhasilanalisisdengan ANAVA satu jalur padatarafsignifikansi 5\%, diperolehnilaiF $F_{\text {hitungsebesar }}$ 230,598 sedangkannilai $F_{\text {tabel }}$ padadb $b_{\text {antar }}=1$ dandb $b_{\text {dalam }}=50$ yaitudiperolehF $F_{\text {tabel }}$ sebesar 4,03. Dengandemikian, makanilai $F_{\text {hitung }}>\mathrm{F}_{\text {tabel, }}$ sehingga $\mathrm{H}_{0}$ ditolak. Hal ini menunjukkan bahwa terdapat pengaruh signifikan antara siswa yang dibelajarkan dengan pendekatan pendidikan matematika realistik berbasis open-ended dengan siswa yang tidak dibelajarkan dengan pendekatan pendidikan matematika realistik berbasis open-ended terhadap kemampuan berpikir kreatif siswa kelas V di Gugus VII Sukasada Tahun Pelajaran 2017/2018.

\section{Pembahasan}

Berdasarkan hasil penelitian, dapat diketahui bahwa pembelajaran menggunakan pendekatan pendidikan matematika realistik berbasis open-ended memiliki efektivitas yang tinggi dan terdapat perbedaan kemampuan berpikir kreatif Matematika antara kelompok siswa yang mengikuti pembelajaran menggunakan pendekatan pendidikan matematika realistik berbasis open-ended dan kelompok siswa yang mengikuti pembelajaran tidak menggunakan pendekatan pendidikan matematika realistik berbasis open-ended. Hal tersebut ditunjukkan oleh perbedaan rata-rata skor, hasil T-Burning dan hasil Anava-A.

Perbedaan tersebut disebabkan oleh hal-hal berikut. Pertama, kelompok siswa yang mengikuti pembelajaran menggunakan pendekatan pendidikan matematika realistik berbasis open-ended diperkenalkan 
dengan pembelajaran yang konstektual dan nyata. Permasalahan yang nyata dan sesuai dengan lingkungan dalam pembelajaran dapat membuat siswa lebih mudah untuk memahami masalah yang ia hadapi. Hal tersebut sesuai dengan pendapat Tarigan (2006:4) yang menyatakan " dengan belajar bersama melalui interaksi dengan lingkungan, siswa mampu membangun dan mengembangkan pengertian dan pengetahuannya”. Selain itu, pembelajaran yang nyata dan sesuai dengan lingkungannya membuat siswa aktif secara fisik dan mental untuk dapat memecahkan masalah yang ia hadapi sehingga pembelajaran menjadi lebih bermakna dan menarik. Hal tersebut juga sesuai dengan pendapat Zulkardi (dalam sri,2002) menyatakan bahwa pembelajaran akan lebih bermakna dan menarik bagi siswa jika guru menghadirkan masalah-masalah kontekstual dan realistic.

Kedua, Dalam setiap pembelajaran, siswa mendapat kesempatan untuk menggunakan berbagai cara penyelesaian/model dalam menyelesaikan masalah yang dihadapi sesuai pengetahuan yang dimiliki sebelumnya dan melatih keterampilan dan kemampuan berpikir. Kegiatan tersebut dapat dilakukan secara baik secara individu maupun kerjasama kelompok/ kelas. Melalui interaksi yang terjadi akan memberikan sebuah pengalaman yanag bermakna sehingga membantu perkembangan kognitif siswa. Schunk (dalam sri, 2008).

Ketiga, masalah yang disajikan dalam bentuk masalah terbuka. Masalah terbuka memberikan kesempatan bagi siswa untuk mencari banyak solusi/penyelesaian sesuai dengan pengetahuannya.selain itu, penggunaan masalah terbuka dalam pembelajaran mampu menumbuhkan kemampuan berpikir kreatif siswa, sejalan dengan hasil penelitian Sudiarta (2003) yang menyatakan bahwa pendekatan open-ended dalam pembelajaran matematika dapat menstimulusi kreativitas berpikir siswa, terutama dalam mengkonstruksi konsep-konsep matematika secara mandiri. Menurut Suherman (2004) dengan menyajikan masalah matematika melalui permasalahan open-ended memicu siswa untuk mengembangkan kemampuan kreatif siswa dalam memecahkan masalah .hal ini dikarenakan permasalahan open-ended memberikan kesempatan kepada siswa untuk mencari banyak jawaban yang benar dengan berbagai alternatif penyelesaian.

Selanjutnya, berkenaan dengan rata-rata skor kemampuan berpikir kreatif Matematika kelompok siswa yang mengikuti pembelajaran tidak menggunakan pendekatan pendidikan matematika realistik berbasis open-ended yang berada pada kategori sedang dipengaruhi oleh beberapa hal berikut. Pertama, Kegiatan inti dalam pembelajaran lebih dominan diisi oleh transfer pengetahuan oleh guru. Guru secara langsung mengajarkan materi/rumus-rumus matematika tanpa memberi kesempatan kepada siswa untuk mengalami proses berpikir. Hal tersebut mengakibatkan terjadinya ketimpangan pada siswa. Siswa yang memiliki konsentrasi tinggi akan efektif menyerap materi yang disampaikan, sedangakan siswa yang tingkat konsentrasinya rendah akan tertinggal dan mudah melupakan materi yang disampaikan. Hal ini sesuai dengan temuan Sri (2004) yang menyatakan pembelajaran yang didominasi oleh guru mengakibatkan pembelajaran menjadi lebih singkat, namun tingkat pemahaman konsep yang dimiliki siwa akan lemah dan mudah untuk dilupakan karena kurangnya pengalaman siswa dalam berpikir. Hal tersebut tentunya akan berpengaruh terhadap kemampuan siswa jika dihadapkan pada permasalahan yang komplek.

Kedua, pembelajaran masih terpaku dengan apa yang ada dalam buku paket. Guru belum mampu mengembangkan materi/permasalahan yang terdapat dalam buku paket menjadi masalah yang kontekstual. Hal tersebut mengakibatkan siswa menjadi kurang nyaman dan termotivasi untuk belajar. Sejalan dengan Putra (2004) yang menyatakan bahwa belajar secara individu dengan menerima, mencatat, dan menghafal materi pelajaran yang tidak dikaitkan dengan kehidupan nyata secara real membuat motivasi siswa menurun. Sebaliknya, dengan menggunakan masalah-masalah kontekstual dalam pembelajaran merangsang terjadinya proses reinvention terhadap konsep-konsep matematika, siswa merasa nyaman dan tidak merasa bosan dalam mengikuti proses pembelajaran.

\section{Simpulan Dan Saran}

Berdasarkan hasil penelitian, dapat disimpulkan bahwa terdapat efektivitas tinggi dan perbedaan kemampuan berpikir kreatif Matematika antara kelompok siswa yang mengikuti pembelajaran menggunakan pendekatan pendidikan matematika realistic berbasis open-ended dan kelompok siswa yang mengikuti pembelajaran tidak menggunakan pendekatan pendidikan matematika realistic berbasis open-ended pada siswa kelas V SD di Gugus VII Kecamatan Sukasada Tahun Pelajaran 2017/2018. Hasil pengujian hipotesis menunjukkan bahwa nilai efektivitas size $(\mathrm{ES})=1,028$ berada pada krentangan $(0,8<1,028)$. Selanjutnya nilai f hitung $(230,598)>\mathrm{ftabel}$ (4.03) yang diuji pada taraf signifikansi 5\% dengan $\mathrm{db}_{\mathrm{antar}}=1$ dandb $\mathrm{b}_{\mathrm{dam}}=50$. Dengan demikian, pendekatan pendidikan matematika realistic berbasis open-ended berpengaruh terhadap kemampuan pemecahan masalah Matematika siswa kelas V SD di Gugus VII Kecamatan Sukasada tahun pelajaran 2017/2018.

Berdasarkan proses dan hasil penelitian yang dilakukan, saran yang dapat disampaikan yaitu sebagai berikut. 1. Kepada Guru

Dalam melaksanakan pembelajaran Matematika khususnya pembelajaran yang realistis dan pemecahan masalah yang terbuka, guru hendaknya menyajikan masalah atau soal yang sesuai dengan kemampuan yang dimiliki siswa. Hal tersebut dapat dilakukan dengan melakukan identifikasi kemampuan awal yang dimiliki siswa melalui pemberian tes. Selain itu, guru hendaknya menambah referensi dan soal-soal pemecahan masalah dari berbagai sumber agar soal yang disajikan dapat lebih beragam.

Pengaruh Pendekatan Pendidikan Matematika Realistik Berbasis Open Ended Terhadap Kemampuan Berpikir Siswa Sd Kelas V 


\section{Kepada Kepala Sekolah}

Berkaitan dengan pembelajaran Matematika, Kepala Sekolah hendaknya mengikutsertakan guru dalam seminar atau pelatihan mengenai pembelajaran pemecahan masalah Matematika. Selain itu, Kepala Sekolah hendaknya mengupayakan untuk menambah referensi buku atau majalah dan sumber lainnya mengenai pembelajaran pemecahan masalah.

3. Kepada Peneliti Lain

Kepada peneliti lain yang ingin melakukan penelitian tentang kemampuan berpikir kreatif Matematika, hendaknya melakukan tes prasyarat untuk mengetahui kemampuan awal siswa. Hal tersebut berguna untuk dapat menentukan materi yang sesuai untuk dibelajarkan kepada siswa. Selain itu, disarankan pula untuk selalu memperhatikan waktu yang tersedia agar penelitian yang dilaksanakan

\section{Daftar Rujukan}

BNSP. (2006). Draft Final Kurikulum Tingkat Satuan pendidikan: Standar Kompetensi Mata Pelajaran Matematika SMA dan MTs. Jakarta: Badan Standar Nasional Pendidikan

Lestari, A. 2014. "Penerapan Pendekatan Realistic Mathematics Education Untuk Meningkatkan Hasil Belajar Siswa pada Materisoal Cerita Tentang Himpunan di Kelas VII MTsN Palu Barat”. Jurnal Eleketronik Pendidikan Matematika Tadulako, Volume 2, Nomor 1 (hlm. 1- 11).

OECD. 2016. Low Performing Students: Why They Fall Behind and How to Help Them Succeed. Paris: OECD Publishing. Tersedia padahttp://dx.doi.org/10.1787/9789264250246-en. Diakses tanggal 5 Juni2018.

Putra, I G B. 2014."Pengaruh Pendidikan Matematika Realistik Terhadap Prestasi Belajar Matematika Ditinjau Dari Motivasi Berprestasi Pada Siswa Kelas Ix Smp Negeri 1 Abang". Jurnal Administrasi Pendidikan. Tersedia pada http://119.252.161.254/e-jurnal/index.php/jurnal_ap/article/download/1412/1086. Diakses pada 25 juni 2018.

Putra, T.T., Irwan., Vionanda, D. (2012). Meningkatkan Kemampuan Berpikir Kreatif Siswa Dengan Pembelajaran Berbasis Masalah. Jurnal Pendidikan Matematika. Vol. 1, No.1, pp 22-26.

Siswono, E. 2007. "Meningkatkan Kemampuan Berpikir Kreatif Siswa Melalui Pemecahan Masalah Tipe What's AnotherWay". Laporan Penelitian. Jurusan Matematika FMIPA UNESA.

Sudiarta, I G P. 2004. Penerapan pembelajaran Berorientasi Masalah "open-ended" berbantuan LKM untuk Meningkatkan Pemahaman dan Hasil Belajar Matematika Mahasiswa pada Mata Kuliah Pengantar Dasar Matematika Semester Ganjil tahun 2004/2005. Singaraja: Undiksha

Sugiyono. 2014. Statistik Untuk Penelitian. Bandung: Alfabeta.

Suherman, H. 2004. Strategi Pembelajaran Matematika Kontemporer. Singaraja: Universitas Pendidikan Ganesha Press.

Susanto, A. 2013. Teori belajar dan pembelajaran di sekolah dasar. Jakarta: Kencana Prenada Media Group.

Sri, W. 2014. "Pengaruh Pendidikan Matematika Realistik Indonesia (Pmri) Terhadap Pemahaman Konsep Dan Berpikir Logis Siswa”. Jurnal Prima Edukasia, Volume 2, Nomor 2 (hlm. 183-192). 